\title{
A VIOLAÇÃO DO DEVER DE INFORMAÇÃO NA FASE PRÉ-CONTRATUAL DO CASAMENTO CIVIL E OS POSSÍVEIS REFLEXOS NA ESCOLHA DO REGIME DE BENS
}

\author{
Beatriz Helena Braganholo ${ }^{1}$
}

\section{NOÇÕES INTRODUTÓRIAS SOBRE O TEMA}

Desde que o mundo existe, as relações afetivas entre homens e mulheres são pautadas por uma série de rituais de passagem. Mesmo após tantos anos, o casamento civil, no Brasil, continua sendo o modelo formal da confirmação e do registro de laços afetivos entre homem e mulher. Frisem-se bem, laços afetivos, porém permeados de efeitos patrimoniais, seja relativamente à sociedade conjugal e formação de patrimônio seja como possibilidades de ingresso no direito sucessório.
Ocorre que na fase pré-contratual, ou seja, durante o processo de habilitação para o casamento civil, procede-se a escolha do regime de bens (no Cartório de Registro Civil das Pessoas Naturais). Pois bem, a escolha diz respeito aqueles que podem optar, aos sujeitos de direitos que a lei civil concede o exercício e a aplicação do princípio da autonomia de vontades. Nesse sentido, o Código Civil vigente afirma em seu artigo 1.639: "É lícito aos nubentes, antes de celebrado o casamento, estipular, quanto aos seus bens, o que lhes aprouver". ${ }^{2}$ Merece destaque que "[...] só subsiste o regime eleito por pacto antenupcial, se fir-

1 Advogada. Mestre em Direito. Especialista em Direito Civil. Aluna do Programa PEC/PPGDIR UFRGS.

2 BRASIL, Lei 10.406 de 10 de janeiro de 2002. Institui o Código Civil. 
mado por noivos que podem escolher livremente o regime patrimonial". ${ }^{3}$

Pode-se, assim, preconizar que somente os excluídos das situações mencionadas pelo artigo 1.641 do Código Civil Brasileiro possuem essa capacidade de exercício pleno do direito de escolha do regime matrimonial. Portanto, as pessoas que casarem com inobservância das causas suspensivas do casamento, que possuírem mais de setenta anos e todos aqueles que dependerem, para casar, de suprimento judicial, ao menos no momento da escolha do regime de bens que irá vigorar ${ }^{4}$, não podem exercer o seu direito de escolha, por determinação legal, devendo aceitar a obrigatoriedade do regime de separação de bens entre os cônjuges. A seguir, retoma-se a questão proposta, prelecionando o conteúdo dos quatro regimes de bens que vigoram no país.

\subsection{Regimes de bens no Brasil: considerações acerca de suas configurações legais}

O regime de bens, também chamado de estatuto patrimonial dos cônjuges, advém de sua natureza contratual, conforme manifesta Sílvio de Salvo Venosa: "A união do homem e da mulher preexiste à noção jurídica. $\mathrm{O}$ casamento amolda-se à noção de negócio jurídico bilateral, na teoria geral dos atos jurídicos. Possui as características de um acordo de vontades que busca efeitos jurídicos. Desse modo, por extensão, o conceito de negócio jurídico bilateral de direito de família é uma especificação do conceito 'contrato'”. ${ }^{5}$

Considerando-se um contrato, mesmo que eivado de características especiais, como o afeto e a "imprevisão” ${ }^{6}$ pelo término, não se pode afas-

3 MADALENO, Rolf. Do regime de bens entre os cônjuges. In: DIAS, Maria Berenice; PEREIRA; CUNHA, Rodrigo da (Coords.). Direito de Família e o Novo Código Civil. 2. ed. Belo Horizonte: Del Rey, 2002. p. 162.

4 Não esquecendo a possibilidade de mutabilidade: alteração do regime de bens entre os cônjuges, mediante autorização judicial, respeitados os elementos do artigo 1.639, parágrafo $2^{\circ}$ do Código Civil.

5 VENOSA, Silvio de Salvo. Direito Civil: Direito de Família. v. 6. 3. ed. São Paulo: Atlas, 2003. p. 40.

6 Partindo-se da máxima de que as pessoas, no geral, casam sem se preocupar, naquele momento, com os efeitos patrimoniais de uma ruptura posterior. 
tar concepções diversas a respeito da natureza jurídica do casamento. Tal como as concepções de natureza jurídica institucional, admitindo o casamento como algo estabelecido pelas leis de uma nação, por ser uma grande instituição social.

Nas palavras de Arnoldo Wald: “É evidente que a densidade do vínculo existente no casamento e a sujeição a normas de ordem pública, que inspiram todo o direito de família, descaracterizam o casamento como contrato. Não é contrato na sua formação, pois necessita de uma intervenção da autoridade pública que não meramente probatório. Não é contrato nos seus efeitos, pois cria deveres legais, que não têm caráter obrigacional. É, assim, uma verdadeira instituição, à qual não se aplicam as normas gerais referentes ao direito das obrigações". ${ }^{7}$

Entre as posições que revelam a caracterização do casamento diversa do contrato, a natureza dita como mista - "o casamento seria um instituto de natureza híbrida: contrato na formação; instituição no conteúdo"8 também não afasta a noção de contrato e seus elementos essenciais, quais sejam: agente capaz, objeto lícito e forma prescrita e não defesa em lei.

Concluindo-se pela natureza jurídica contratual do casamento civil, verifica-se que no contrato as partes estipulam condições e termos, pois, no pacto antenupcial, podem-se adicionar cláusulas e disciplinar as relações conjugais, porém não de forma contrária à estabelecida em lei.

A amplitude do tema merece uma análise mais aprofundada dos quatro regimes de bens que vigoram no país, concentrando-se, inicialmente, nas características do conteúdo de cada um deles. Observe-se a importância dessas informações para que os nubentes verifiquem qual deles preenche as condições que desejam estipular.

\subsubsection{Regime da comunhão parcial de bens}

É tido como o regime oficial, também chamado de regime legal de bens, desde o advento da Lei do Divórcio (6.515), em 15 de dezembro de 1977. Segundo o artigo 1.640: "Não havendo convenção, ou sendo ela nula ou ineficaz, vigorará, quanto aos bens, o regime da comunhão

7 WALD, Arnoldo. O Novo Direito de Família. 14. ed., ver. e atual. São Paulo: Saraiva, 2002. p. 54-55.

8 LEITE, Eduardo de Oliveira. Direito Civil Aplicado: Direito de Família. v. 5. São Paulo: RT, 2005. p. 49. 
parcial”. No caso deste regime, dispensa-se a realização do pacto antenupcial, advindo "[...] um regime de separação quanto ao passado e de comunhão quanto ao futuro". ${ }^{9}$

Neste regime comunicam-se todos os bens adquiridos durante a vigência da sociedade conjugal, a título oneroso, sendo particulares os bens que cada cônjuge possuía ao casar e os que lhe sobrevierem, na constância do matrimônio, por doação, sucessão ou sub-rogados a estes, em conformidade com os artigos 1.659 e 1.661 do Código Civil. Portanto, "formam-se três massas de bens: os bens do marido, os bens da mulher e os bens comuns". ${ }^{10}$

Destacando-se o teor do artigo 1.660, incisos I ao IV do Código Civil, ao informar o ingresso na comunhão dos bens a título oneroso, ainda que só no nome de um dos cônjuges, os adquiridos por fato eventual, por doação, herança ou legado, em favor de ambos os cônjuges e as benfeitorias em bens particulares de cada um dos cônjuges. E ainda, a incomunicabilidade não alcança frutos dos bens, independente se advindos dos bens particulares ou comuns, em conformidade com o art. 1.660, inciso V do Código Civil.

\subsubsection{Regime da comunhão universal de bens}

Antes do advento da Lei 6.515, de 1977, era o regime oficial, visto que atendia a uma realidade diversa da atual, qual seja, as pessoas casavam mais cedo e adquiriam seu patrimônio, essencialmente, durante o casamento. Assim, entendia-se como sociedade conjugal a comunhão de todos os bens presentes e futuros, conforme está previsto no artigo 1.667 do Código Civil.

A particularidade do regime leva à noção de que há “[...] praticamente, uma despersonalização do patrimônio individual, surgindo um patrimônio indivisível e comum, sem definir especificar ou localizar a propriedade nos bens". Merece ser observado, que essa comunhão de vida e de bens deve ser manifestada por escolha, quando possível, e pela realização de um pacto antenupcial, o qual nada impede, podendo excluir ou incluir alguns bens, sem descaracterizar o curso do regime.

Sem dúvida, os bens mencionados no artigo 1.668, permanecem patrimônio particular de cada um dos consortes, não pertencendo aos dois

9 RODRIGUES, Sílvio. Direito civil: Direito de família. 27. ed. Atual. por Francisco José Cahali, com anotação ao novo Código Civil. São Paulo: Saraiva, 2002. p. 206.

10 MADALENO, Rolf. Do regime de bens entre os cônjuges. In: DIAS, Maria Berenice; PEREIRA; CUNHA, Rodrigo da (Coords.). Direito de Família e o Novo Código Civil. 2. ed. Belo Horizonte: Del Rey, 2002. p. 167. 
cônjuges nem possibilitando ingresso na sociedade conjugal. Dá-se destaque os gravames restritivos do direito à propriedade, como no caso dos bens doados ou herdados com cláusula de incomunicabilidade e todos àqueles sub-rogados em seu lugar (artigo 1.668 e seus incisos), salvaguardados pelo legislador para proteger o sagrado direito à propriedade.

\subsubsection{Regime da separação de bens e a separação obrigatória ou legal}

Sem dúvida, dos quatro regimes, este é o que preserva a individualidade do patrimônio de cada um dos cônjuges. Todavia, duas ressalvas são importantes: primeiramente, a existência do regime de separação total ou absoluta de bens por livre conveniência das partes, disposto no respectivo pacto de bens e passível de várias formas de elaboração do conteúdo desse contrato e suas respectivas cláusulas; outra, a existência da imposição, advinda da lei, quando incorrer nas hipóteses consignadas no artigo 1.641, da separação obrigatória de bens.

Leve-se em consideração a discussão acerca da aplicação ou não da Súmula n. 377 do Supremo Tribu- nal Federal que define: "No regime de separação legal de bens, comunicam-se os adquiridos na constância do casamento". Nesse sentido, Arnaldo Rizzardo esclarece: "No regime de separação legal, a exegese mais correta é a que sustenta a comunicabilidade dos aquestos, quando formados pela atuação comum do marido e da mulher". ${ }^{11}$

De qualquer sorte, parece que o Código Civil não pretendia seguir o que a jurisprudência já vinha adotando, quando da aplicação da súmula n. 377 do STF, caso contrário, poderia ter excluído os casos de obrigatoriedade do regime de separação legal de bens. Conclusão lógica é de a aplicação da Súmula determinar regime de bens diverso do prelecionado pela legislação infraconstitucional, ou melhor, pelo silêncio da lei civil.

De qualquer forma, autorizada sua aplicação, temos um regime determinante de comunicação dos bens adquiridos na constância do casamento, obviamente, resultantes de esforço comum presumido. Não sendo esse somente caracterizado quando decorre de trabalho específico numa atividade econômica, com atuação fora do lar e percepção de remuneração, mas, sim, no apoio emocional, sem atuação

11 RIZZARDO, Arnaldo. Direito de família: Lei n. 10.406, de 10.01.2002. Rio de Janeiro: Forense, 2005. p. 662. 
profissional lucrativa, envolvendo administração da casa, cuidados com os familiares e presença constante na forma de constituir família.

Nesse sentido, fica evidente o dever de atendimento quanto a repersonalização da família, ou seja: "[..] resgate de todos os valores imateriais que devem existir no seio familiar e que são os efetivos responsáveis por sua manutenção. Entre eles: afetividade, liberdade, diálogo, compreensão, carinho e toda característica que prestigie o mútuo respeito". ${ }^{12}$

No tocante ao livre-direito de escolha, de comum acordo, persistirá a existência de patrimônio distinto, não havendo a construção da chamada sociedade conjugal no aspecto patrimonial. Nesse sentido, respeitam-se a autonomia e personalidade de cada um dos nubentes, possibilitando aos noivos, por exemplo, casar pelo regime da separação de bens, mas definindo expressamente que um determinado imóvel seja comum entre ambos. Nesse caso, o oficial registrador, conforme o pacto antenupcial, deverá celebrar o casamento pelo regime base (separação de bens), cabendo aos cônjuges, quando do término ou dissolução da sociedade conjugal, ${ }^{13}$ trazer em juízo tal fato para a partilha do bem especificado. Nada impede, se determinados bens forem adquiridos em comum, que seja expressamente estabelecido um condomínio.

Mesmo estabelecido o regime de separação de bens, na forma total, plena ou absoluta, essa não elide o reconhecimento da sociedade de fato, desde que tenha havido esforço comum para a formação do patrimônio, caso contrário, poderia ser considerado enriquecimento indevido. A interpretação pode ser outra, se a disposição em pacto estabelecer forma diversa em caso de atuação comum da esposa e do marido, porém com registro em nome exclusivo de um dos cônjuges.

Resta saber como podem aceitar a imposição do regime de separação nos casos obrigatórios sem compreender as possibilidades posteriores, ou seja, na dependência de uma orientação emanada, futuramente, pelos tribunais. Situação diversa é atribuída àqueles que optam por permanecer, na sociedade conjugal, com patrimônios distintos e particulares (separação absoluta), podendo, inclusive, dispensar a autorização do outro cônjuge para

12 OLIVEIRA, José Sebastião de. Fundamentos Constitucionais do Direito de Família. São Paulo: Editora Revista dos Tribunais, 2002. p 248.

13 A sociedade conjugal termina: pelo falecimento, nulidade ou anulação, pela separação ou divórcio - art. 1571, incisos I ao IV; dissolve: morte ou pelo divórcio - art. 1.571, § $1^{\circ}$ do NCC. 
alienar ou gravar de ônus real bens imóveis, pleitear acerca de seus direitos como autor ou réu, prestar fiança ou aval e fazer doação de seus bens, sabendo-se que não haverá meação decorrente do regime escolhido. ${ }^{14}$

\subsubsection{Participação final nos aquestos}

Novidade, surgida com o advento do novo Código Civil, já nasce carente de compreensão, situação demonstrada pela realidade fática. ${ }^{15}$ Trata-se de um regime misto, de difícil compreensão prática. Assim, durante a constância do casamento, vigora o regime da separação de bens ${ }^{16}$, com administração exclusiva do seu próprio patrimônio, podendo livremente os alienar se forem móveis. ${ }^{17}$ Entenda-se patrimônio próprio, todo aquele que "cada cônjuge possuía ao casar e por ele adquirido, a qualquer título, na constância do casamento". ${ }^{18}$

Entretanto, advindo a dissolução da sociedade conjugal, a lei determina re- gime diverso, passando-se, em termos gerais, ao regime de comunhão parcial de bens, respeitadas as considerações do artigo 1.674: "Sobrevindo a dissolução da sociedade conjugal, apurar-se-á o montante dos aquestos, excluindo-se da soma dos patrimônios próprios: I. os bens anteriores ao casamento e os que em seu lugar se sub-rogaram; II. os bens que sobrevieram a cada cônjuge por sucessão ou liberalidade; III. as dívidas relativas a esses bens".

É imperioso ressaltar, que salvo prova em contrário, presume-se adquiridos durante o casamento os bens móveis, ou seja, não conseguindo prova em contrário, o bem móvel de patrimônio individual ou próprio, passa a configurar conteúdo dos aquestos. ${ }^{19}$ É situação idêntica àquela no regime de comunhão parcial, quando há presunção de aquisição durante a constância do casamento, não se provando data anterior em caso de bens móveis. ${ }^{20}$

No pertinente aos bens imóveis, o teor do artigo 1.681 é taxativo: "Os

14 Em conformidade com o teor do artigo 1.647 e incisos do Código Civil.

15 Na cidade de Passo Fundo, RS, até a data de 27 de junho de 2005, só há um pacto antenupcial realizado diante da escolha deste regime.

16 Não se aplicando a incidência do disposto no artigo 1.647 e incisos do Código Civil. 17 Conforme artigo 1.673, parágrafo único, do Código Civil.

18 Conforme artigo 1.673, caput, do Código Civil.

19 Conforme artigo 1.674, parágrafo único, do Código Civil.

20 Conforme artigo 1.661, do Código Civil. 
bens imóveis são de propriedade do cônjuge cujo nome constar no registro”. Segue-se em seu parágrafo único: "Impugnada a titularidade, caberá ao cônjuge proprietário prova a aquisição regular dos bens". ${ }^{21} \mathrm{~A}$ inversão do ônus da prova, neste caso, demonstra que o regime, em caso de ruptura conjugal, não adquire feições idênticas ao regime de comunhão parcial de bens. Tendo em vista que os bens imóveis, no conteúdo do regime de comunhão parcial de bens, neste caso, fariam parte da meação dos cônjuges, não importando, de regra, o nome constante no registro, se adquiridos onerosamente na constância do casamento. ${ }^{22}$

É de salientar que as dívidas, sendo superiores à meação, não obrigam o outro cônjuge ao seu pagamento, mormente aos seus herdeiros. ${ }^{23}$ Como qualquer forma de ajuda mútua, é entendida em termos de sociedade empresarial, na inteligência do artigo 1.678, "se um dos cônjuges solveu a dívida do outro com bens de seu patrimônio, o valor deve ser imputado e atualizado, na data da dissolução, à meação do outro cônjuge”. Por isso, se o casamento perdurar por muitos anos, certamente os bem informados e prevenidos guardarão comprovantes e mais comprovantes a fim de não ter surpresas no final, ou melhor, em caso de dissolução. Pergunta-se: não poderia ser caso de notória alegação de má-fé, pois, tradicionalmente, ninguém, a menos que pretenda romper com a união, acaba por guardar ao longo de uma vida feliz em comum uma série de notas e demonstrativos fiscais?

Por fim, o direito à meação não é renunciável, cessível ou penhorável na vigência do regime matrimonial, ${ }^{24}$ entendendo-se, portanto, nula cláusula em pacto antenupcial que dispusesse forma contrária. ${ }^{25}$

Para ingressar-se no ponto relativamente a ocorrência de violação das garantias constitucionais, em caso de não atendimento ao dever de informação, deve-se analisar do seguinte prisma: “A Constituição passa a ser o centro do ordenamento e a influenciar a interpretação de todas as normas infraconstitucionais”. ${ }^{26}$

21 Necessitariam consultar um criterioso advogado familiarista, o que não é praxe no Brasil, antes do casamento, mormente para administrar consequências desta escolha.

22 Em conformidade com o artigo 1.660, inciso I do Código Civil, lembrando que a tradição patrimonialista evidencia o registro no nome do marido, em caso de bens.

23 Conforme artigo 1.686, do Código Civil.

24 Conforme artigo 1.682, do Código Civil.

25 Conforme artigo 1.655, do Código Civil.

26 DONADEL, Adriane. Efeitos da Constitucionalização do Direito Civil no Direito de Família. In: PORTO, Sergio Gilberto (Org.). Tendências constitucionais no Direito de Família. Porto Alegre: Livraria do Advogado, 2003. p. 13. 


\section{POSSIBILIDADE DE VIOLAÇÃO DAS GARANTIAS CONSTITUCIONAIS E CONTRATUAIS}

O direito à liberdade e a propriedade inscreve-se na matriz teórica dos direitos e garantias fundamentais, elencados no artigo $5^{\circ}$ caput e inciso V, da Constituição Federal de 1988, como garantia constitucional do "direito à liberdade e a propriedade”, estabelecendo no inciso XXII o direito a propriedade. Consagra-se, portanto, a inviolabilidade desses direitos, estabelecendo limites dentro do pacto antenupcial/contrato, assegurando a propriedade e a consequente indenização pela violação das cláusulas contratadas, em face dos danos morais, materias ou à imagem provocados.

\subsection{Direito à liberdade: atendimento ao princípio da autonomia de vontade $e$ princípio da mutabilidade do regime de bens}

O direito à liberdade, ou seja, a liberdade de escolha do regime de bens diante do tema proposto, somente poderá ser pleno se atendido o dever de informar, ainda que na fase pré-contratual, e não havendo inclusão nos casos condicionados às situações do artigo 1.641 da legislação infraconstitucional civil vigente. ${ }^{27}$ Assim, podemos concluir que nesses casos não haverá atendimento ao princípio da autonomia de vontade, pois em meio a uma aparência protetiva, lembrando-se das propriedades de cada um dos cônjuges, não do seu direito de escolha, ocorre a violação da liberdade na autonomia de decisão e, ao menos no teor infraconstitucional, impedindo, em alguns casos, a posterior mudança no regime de bens.

As razões para tal encontram respaldo em concepções antigas, resultantes do longo período em que tramitou o projeto do novo Código Civil, agora vigente. Comprovando tal posição, tem-se a imagem traduzida nos casos em que haveria justo motivo para o legislador impor limites quanto à autonomia de vontade, na livre escolha do regime de bens, pelo exclusivo fato da pessoa possuir idade biológica superior aos setenta anos ${ }^{28}$.

27 Conforme considerações feitas nas noções introdutórias sobre o tema e no item 1.2.3, Regime da separação de bens e a separação obrigatória ou legal, do presente artigo. 28 Isso porque com a edição da lei 12.344 de 2010, a idade para a imposição do regime da separação obrigatória de bens mudou de 60 (sessenta) para 70 (setenta) anos. 
É importante ressaltar que "O princípio da liberdade diz respeito ao livre poder de escolha ou autonomia de constituição, realização e extinção de entidade familiar, sem imposição ou restrições externas de parentes, da sociedade ou do legislador; à livre aquisição e administração do patrimônio familiar; ao livre planejamento familiar; à livre definição dos modelos educacionais, dos valores culturais e religiosos; à livre formação dos filhos, desde que respeite suas dignidades como pessoas humanas; à liberdade de agir, assentada no respeito à integridade física, mental e moral". ${ }^{29}$

Em face ao art. $1^{\circ}$, inciso III, da Constituição Federal, e a inconstitucionalidade do art. 1641, inciso II, no atual Código Civil, reafirma-se preconceituosa regra permitida anteriormente pelo legislador brasileiro. Como resultado, chega-se a conclusão de que a restrição imposta é inconstitucional ante o atual sistema jurídico que tutela a dignidade da pessoa humana, violando o direito à liberdade e a propriedade. Revela-se de todo des- cabida a presunção de incapacidade por implemento de idade.

Nesta linha, valem os argumentos extraídos da noção de constitucionalização do direito de família, assim: "Quando a legislação civil for claramente incompatível com os princípios e as regras constitucionais, deve ser considerada revogada, se anterior à Constituição, ou inconstitucional, se posterior a ela. Quando for possível o aproveitamento, observar-se-á a interpretação conforme a Constituição. Em nenhuma hipótese deverá ser adotada a disfarçada resistência conservadora, na conduta frequente de se ler a Constituição a partir do Código Civil”. ${ }^{30}$

Todavia, o Tribunal de Justiça do Rio Grande do Sul, em decisão posterior a vigência do novo Código, afirmou que "[...] A restrição imposta no inciso II do art. 1641 do Código vigente, correspondente ao inciso II do art. 258 do Código Civil de 1916, é inconstitucional, ante o atual sistema jurídico que tutela a dignidade da pessoa humana como cânone maior da

29 LÔBO, Luiz Paulo Netto. Constitucionalização do Direito Civil. Jus Navegandi, Teresina, ano 3, n. 33, jul. 1999. Disponível em: <http://www1.jus.com.br/doutrina/ texto.asp?id=507>. Acesso em: 30 maio 2004, p. 8.

30 LÔBO, Luiz Paulo Netto. Constitucionalização do Direito Civil. Jus Navegandi, Teresina, ano 3, n. 33, jul. 1999. Disponível em: <http://www1.jus.com.br/doutrina/ texto.asp?id=507>. Acesso em: 30 maio 2004, p.12-13. 
Constituição Federal, revelando-se de todo descabida a presunção de incapacidade por implemento de idade." ${ }^{\text {1 }}$

O Desembargador José Carlos Teixeira Giorgis, na mesma decisão, afirma em seu voto: "Modestamente aporia mais um elemento nesta linha. É que, inclusive no regime da separação obrigatória, na vigência do antigo Código, o próprio Supremo Tribunal Federal já havia decretado a possibilidade da comunhão dos aquestos, o que representava, mediante a Súmula n. 377, uma verdadeira perfuração da rocha monolítica, como era considerada a separação. Com a entrada em vigor do Novo Código, questiona-se se esta Súmula estaria ainda em vigor, mas a festejada doutrina dos comentadores do Código entende que se manteria, portanto, o regime da comunhão dos aquestos". ${ }^{32}$

Nos demais casos, do art. 1641, no inciso I, do atual Código Civil, observa-se que àqueles que realizarem o casamento com inobservância das causas suspensivas, mencionadas no artigo $1.523^{33}$, por questões práticas, evitando a confusão de patrimônios no momento da identificação, seriam beneficiadas com a determinação legal, portanto, não estando impedidos da alterabilidade do regime de bens, cessadas as causas suspensivas.

Já o inciso II, nos casos em que for concedido suprimento judicial para os menores de dezesseis anos ${ }^{34}$, entende-se não existir obstáculo para futura alteração do regime de bens, desde que atendidas as exigências do artigo 1.639 , parágrafo $2^{\circ}$ do Código Civil.

Inobstante, a posição manifestada pelo desembargador Luiz Felipe Brasil Santos, é a seguinte: "Não será possível a modificação do regime de bens daqueles casais que celebram o matrimônio nas circunstâncias do artigo 1.641, incisos, I, II e II, estando sujeitos, assim, ao regime obrigatório da separação de bens, salvante a hipótese de terem obtido a não aplica-

31 Tribunal de Justiça do Rio Grande do Sul, Apelação Cível n. 70004348769, Rel. Des. Maria Berenice Dias, julgada em de 27 de agosto de 2003. [grifo nosso]

32 Tribunal de Justiça do Rio Grande do Sul, op. cit., 2003.

33 São circunstâncias que permitem o casamento se houver autorização judicial, pois, ainda que infringidas, não constituem invalidação do ato. Adverte-se que às pessoas nestas condições será determinado o regime de separação obrigatória de bens.

34 Em casos excepcionais será permitido o casamento daqueles que não atingiram a idade núbil, conforme teor do artigo 1.520 do Código Civil. 
ção das causas suspensivas, conforme previsão do parágrafo único do artigo 1.523 [...]. Interessante hipótese, no entanto, ocorrerá [...] vindo mais tarde, ao longo do casamento a desaparecer a causa suspensiva (v.g., um divorciado que não realizara a partilha e que venha depois a completá-la). Neste caso, tenho que nenhuma razão haverá que impeça a mudança do regime de bens $[\ldots . .]^{\prime 3}{ }^{35}$

Especificamente, as exceções ao princípio da autonomia de vontades estão apontadas no artigo 1.640: "Não havendo convenção, ou sendo ela nula ou ineficaz, vigorará, quanto aos bens entre os cônjuges, o regime da comunhão parcial”. E também, nos casos em que a lei impõe a submissão, não havendo livre disposição, conforme está disposto no artigo 1.641 do Código Civil: "É obrigatório o regime de separação de bens no casamento: I. Das pessoas que contraírem com inobservância das causas suspensivas da celebração do casamento; II. Da pessoa maior de sessenta anos; III. De todos que dependerem, ara casar, de suprimento judicial”.

Nesse sentido, Orlando Gomes afirma que "Os nubentes podem escolher, em princípio, o regime que lhes convenha, não estando adstritos, sequer, à adoção de um dos tipos, tal como se acham definidos em lei, eis que podem combiná-los, formando regime misto, uma vez respeitadas as disposições legais de ordem pública. [...]. Na escolha há liberdade, mas o legislador por motivo de precaução ou para punir os nubentes, impõe, em certos casos, determinado tipo (regime obrigatório)". ${ }^{36}$

Ressalva-se que somente havendo possibilidade de escolha entre os quatro regimes (ou mesmo combinados entre si) ${ }^{37}$, sendo atendido o dever de informação e, portanto, conhecendo as consequências contratuais ou extracontratuais, é possível afirmar pelo respeito ao exercício dos direitos fundamentais, incluindo-se a "[...]autonomia pessoal, isto é, na liberdade (no sentido de capacidade para liberdade)"”. ${ }^{38}$

35 Artigo de sua autoria veiculado no site < http://www.migalhas.com.br/mostra noticia_articuladas.aspx?cod=2295>.

36 GOMES, Orlando. Direito de Família. Atual. por Humberto Theodoro Júnior. Rio de Janeiro: Forense, 2002. p. 172.

37 A exemplo de cláusula em pacto antenupcial determinando a inclusão ou exclusão de algum bem móvel ou imóvel em regime de comunhão universal de bens.

38 SARLET, Ingo Wolfgang Sarlet. Dignidade da pessoa humana e direitos fundamentais na Constituição Federal de 1988. Porto Alegre: Livraria do advogado, 2001. p. 87. 
Como reflexo, para concretização do direito à liberdade pessoal "como expressão da autonomia da pessoa humana (e, portanto, de sua dignidade) reclama-se a possibilidade concreta de participação na formação da vontade geral" ${ }^{39}$

Daí se conclui que o legislador estabeleceu, por meio de critérios sociais, para quem deve vigorar o princípio da liberdade ou é garantido o princípio da autonomia de vontade, quanto à possibilidade de escolha do regime de bens no casamento.

\section{2 Direito à propriedade: respeito ao direito à informação}

$\mathrm{O}$ inciso XXII, no artigo $5^{\circ} \mathrm{da}$ Carta Magna, estabelece o direito a propriedade, estando este ponto inteiramente ligado à questão da vocação hereditária. Como se vê, em seu artigo $5^{\circ}$, inciso XXX, preleciona: "é garantido o direito de herança”.

Sobre o conceito de propriedade deduzido da Constituição, ensina Luiz Paulo Netto Lôbo: “A concepção de propriedade, que se desprende da Constituição, é mais ampla que o tradicional domínio sobre coisas corpó- reas, principalmente imóveis, que os códigos civis ainda alimentam. Coenvolve a própria atividade econômica, abrangendo o controle empresarial, o domínio sobre ativos mobiliários, a propriedade de marcas, patentes, franquias, biotecnologias e outras propriedades intelectuais". ${ }^{40}$

Como se infere, não se deve afastar a possibilidade de total desconhecimento, por parte dos nubentes, de que o patrimônio amealhado em vida pelos cônjuges e mesmo após o falecimento de um deles, pode não ter o destino imaginado. Explicando melhor, ao optarem por um dos regimes matrimoniais, se não seguirem o tradicional regime dito oficial, portanto, sem a necessidade de pactuar ou de maiores gastos, a construção futura do patrimônio pode ser muito diversa do imaginado inicialmente. É bom lembrar que o conteúdo do regime a vigorar entre eles após a realização das núpcias, bem como as informações a respeito do conteúdo que perfaz os regimes são dadas pelos oficiais de registro civil ou seus representantes do Cartório de Registro Civil das Pessoas Naturais.

39 SARLET, Ingo Wolfgang Sarlet. Dignidade da pessoa humana e direitos fundamentais na Constituição Federal de 1988. Porto Alegre: Livraria do advogado, 2001. p. 94. 40 LÔBO, Luiz Paulo Netto. Constitucionalização do Direito Civil. Jus Navegandi, Teresina, ano 3, n. 33, jul. 1999. Disponível em: <http://www1.jus.com.br/doutrina/ texto.asp?id=507>. Acesso em: 30 maio 2004, p. 11. 
No caso dos regimes de separação convencional de bens absoluta, não há que se falar em patrimônio comum. Nestes casos, temos patrimônios individuais - distintos - e não há patrimônio comum como regra.

Aliás, "meação não é herança" ${ }^{41}$ Segue, nesse sentido, Silvio de Salvo Venosa: "Como em qualquer outra sociedade, os bens comuns, isto é, pertencente às duas pessoas que foram casadas, devem ser divididos. A meação é avaliada de acordo com o regime de bens que regulava o casamento. [...] Se há pacto antenupcial, a meação será encontrada de acordo com o estabelecido nessa escritura. Portanto, ao se examinar uma herança no falecimento de uma pessoa casada, há que se separar do patrimônio comum (portanto, um condomínio) o que pertence ao cônjuge sobrevivente, não porque o seu esposo morreu, mas porque aquela porção ideal do patrimônio lhe pertencia”, ${ }^{42}$

Por fim, justifica-se que a natural inibição dos nubentes ao tratar questões patrimoniais antes do casamento, pelo constrangimento característico da situação, pode levar a escolhas erradas quanto ao regime, ou melhor, o desconhecimento do conteúdo de cada regime de bens, quais os bens que permanecem como patrimônio particular ou farão parte da meação (se houver). Assim, não seriam atendidos os princípios constitucionais do direito à propriedade e do direito à liberdade, visto que a escolha não seria livre, pelo próprio desconhecimento das características de cada um dos regimes, resultando em importantes consequências na esfera contratual-patrimonial, protegida pelo direito a propriedade, no caso de não atendimento ao princípio da boa-fé.

\section{PRINCIPAIS \\ CONCLUSÕES A RESPEITO DO DEVER DE INFORMAR NA FASE PRÉ-CONTRATUAL DO CASAMENTO CIVIL NO BRASIL}

Necessário se faz mencionar que o desconhecimento do conteúdo e as limitações de cada regime acabam por inibir e, consequentemente, por impedir o livre-acesso à informação se a escolha se realizar sem conhecimento real acerca do conteúdo, limites e possíveis consequências patrimoniais de cada regime. Como alguém pode ser

41 VENOSA, Silvio de Salvo. Direito Civil: Direito das Sucessões. v. 7. 3. ed. São Paulo: Atlas, 2003. p. 104.

42 VENOSA, Silvio de Salvo. Direito Civil: Direito das Sucessões. v. 7. 3. ed. São Paulo: Atlas, 2003. p. 105. 
livre para escolher, nos casos permitidos pela lei (salvo nos casos do regime obrigatório de separação de bens), desconhecendo o teor e as consequências legais de cada regime de bens?

A própria Constituição Brasileira afirma no caput do seu artigo $5^{\circ}$, que todos são iguais perante a lei, sem distinção de qualquer natureza, garantindo-se a inviolabilidade do direito à liberdade e à propriedade. ${ }^{43}$

Como se vê, para que os nubentes possam fazer escolhas livres é preciso conhecer o conteúdo dos quatro regimes de bens, as possibilidades de conteúdo das disposições contratuais (cláusulas em pacto antenupcial) e, ainda, as possibilidades de inclusão como herdeiro (em caso de falecimento). Resta saber se o Cartório de Registro Civil das Pessoas Naturais, como órgão competente para tal, está apto a elucidar questões envolvendo tamanha complexidade nos breves momentos anteriores à escolha do regime matrimonial. Aliás, não é demais lembrar que os nubentes maiores de setenta anos não podem, sequer, questionarar a respeito das possibilidades na escolha por um dos quatro regimes (não sendo regime de separação obrigatória de bens).
Destaca-se ainda a evidente e natural inibição no momento da escolha do regime de bens, conforme Débora Gozzo "Os nubentes, na sua grande maioria, se sentem constrangidos para discutir questões de cunho patrimonial antes do casamento. É uma inibição natural, que pode levar a escolhas erradas quanto ao regime [...]". ${ }^{44}$

Na esfera da informação pré-matrimonial, o desconhecimento vicia, gerando uma escolha ou elaboração de pacto antenupcial sem o atendimento ao princípio contratual do dever de informação. Caso fique evidenciado o desconhecimento do conteúdo de cada um dos quatro regimes, a escolha não seria livre, tendo em vista o próprio desconhecimento das características e dos efeitos patrimoniais de cada um dos regimes, gerando, assim, importantes consequências na esfera patrimonial, protegida pelo direito a propriedade.

Com o advento da despatrimonialização e o surgimento do fenômeno da repersonalização tornou-se importante "repor a pessoa como centro do direito civil, passando o patrimônio para segundo plano”, porém, não significando "[...] que haja o completo

43 BRASIL. Constituição (1988). Constituição da República Federativa do Brasil. Brasília, DF: Senado, 1988.

44 GOZZO, Débora. Pacto Antenupcial. São Paulo. Saraiva, 1992. p. 126. 
abandono da regulamentação acerca do patrimônio". ${ }^{45}$

O não atendimento à liberdade individual na possibilidade de escolha consciente, compreendendo os reflexos patrimoniais ${ }^{46}$ advindos da relação matrimonial, refletem no não atendimento aos direitos fundamentais preconizados pela Constituição Cidadã de 1988.

Faz-se necessário perceber que, no plano do direito, existem os sujeitos de direito ${ }^{47}$ e aqueles com direitos hipotéticos - que apenas são parte de um conceito formal definido pela lei. Isso leva a admitir uma injusta e desigual ordem social, na qual poucos podem figurar em situação de igualdade. Em outras palavras, há uma "igualdade jurídica a que não corresponde uma igualdade real". ${ }^{48}$

Afinal, quem é o sujeito de direito no sistema jurídico brasileiro?
Para o sistema jurídico de direito civil, e, portanto, esse sistema de direito privado codificado e edificado $^{49}$, os sujeitos nas suas relações aparecem como pessoas juridicamente iguais ${ }^{50}$. Ocorre que determinados sujeitos podem estar fora dessa classificação: mesmo sendo pessoas, não são, necessariamente, sujeitos de um determinado direito, como ocorre nos casos do casamento os maiores de setenta anos, quando o sistema determina e regula juridicamente os limites da liberdade, oferecendo suposta proteção $^{50}$ tão somente aos que não ultrapassam os limites estabelecidos pelo poder público.

Cabe ao Direito estabelecer a concretização dos valores fundamentais do ser humano, com base nos seus instrumentos jurídicos, operacionalizando o alcance dos interesses, a realização de atos e atividades dos

45 DONADEL, Adriane. Efeitos da Constitucionalização do Direito Civil no Direito de Família. In: PORTO, Sergio Gilberto (Org.). Tendências constitucionais no Direito de Família. Porto Alegre: Livraria do Advogado, 2003. p. 14.

46 Entendendo-se que os reflexos extrapatrimoniais não podem ser atribuídos ao serviço notarial.

47 Sujeito de direito: “aquele que tem bens, patrimônio sobre si, compra, vende, pode testar, e até contrai núpcias”. Conforme FACHIN, Luiz Edson. Limites e Possibilidades da Nova Teoria Geral do Direito Civil. In: Jurisprudência cível e do comércio, 172, Série. Paraná: Curitiba, 1994, p.49.

48 CARVALHO, Orlando de. A Teoria Geral da Relação Jurídica: seu sentido e limites. 2. ed. atual. Coimbra: Centelha, 1981. p. 11.

49 Hoje é inaceitável a rígida contraposição entre o Direito Público e o Privado.

50 Visão ultrapassada diante da realidade da constitucionalização do direito civil. 
indivíduos, para que os mesmos "não contrastem com a segurança, liberdade e dignidade humana". ${ }^{51}$

A intervenção estatal nas relações privadas deve vir acompanhada do acesso à informação, impedindo a vitória de uma aparente liberdade e uma autonomia de vontade limitada, zelando pelo direito à informação dos contraentes. Visto que os desfavorecidos não têm consciência da verdadeira justiça e por desconhecerem as limitações do conteúdo dos regimes de bens do casamento civil, esperam benefícios que dificilmente lhes são concedidos.

\section{REFERÊNCIAS}

BRASIL, Constituição (1988). Constituição da República Federativa do Brasil. Brasília, DF: Senado, 1988.

BRASIL, Lei 10.406 de 10 de janeiro de 2002. Institui o Código Civil. Brasília, DF: Senado, 1988.

BRASIL, Lei 12.344 de 09 de dezembro de 2010. Altera a redação do inciso II do art. 1.641 da Lei n. 10.406, de 10 de janeiro de 2002 (Código Civil), para aumentar para 70 (setenta) anos a idade a partir da qual se torna obrigatório o regime da separação de bens no casamento, DF: Senado, 2010.

BRASIL, Tribunal de Justiça do Rio Grande do Sul. Apelação Cível n.
70004348769 da $7^{\text {a }}$ Câmara Cível. Rel.: Des. Maria Berenice Dias. Julgado em: 27 ago. 2003.

BRASIL, Tribunal de Justiça do Rio Grande do Sul. Agravo de Instrumento n. 70013119425, Rel.: Des. Luiz Felipe Brasil Santos. Julgado em: 21 dez. 2005.

BRASIL, Tribunal de Justiça do Rio Grande do Sul. Agravo de Instrumento n. 70013227533. Relator: Ricardo Raupp Ruschel, Tribunal de Justiça do RS. Julgado em: 21 dez. 2005.

BITTAR, Carlos Alberto. A propriedade e os direitos reais na Constituição de 1988. São Paulo: Saraiva, 1991.

51 Proteção dita infraconstitucional e no momento de processo de habilitação para o casamento civil, quando não será realizado pacto antenupcial, apenas constando a observação do regime obrigatório de bens. 
CARVALHO, Orlando de. A Teoria Geral da Relação Jurídica: seu sentido e limites. 2. ed. atual. Coimbra: Centelha, 1981.

DONADEL, Adriane. Efeitos da Constitucionalização do Direito Civil no Direito de Família. In: PORTO, Sergio Gilberto (Org.). Tendências constitucionais no Direito de Família. Porto Alegre: Livraria do Advogado, 2003.

FACHIN, Luiz Edson. Limites e Possibilidades da Nova Teoria Geral do Direito Civil. In: Jurisprudência cível e do comércio, 172. Série. Paraná: Curitiba, 1994.

GEHLEN, Gabriel Menna B. Von. O chamado Direito Civil Constitucional. In: COSTA, Judith Martins (Org.). A reconstrução do Direito Privado: Reflexos dos princípios, diretrizes e direitos fundamentais constitucionais no direito privado. São Paulo: Revista dos Tribunais, 2002. p.174-209.

GOMES, Orlando. Direito de Família. Atual. Humberto Theodoro Júnior. Forense: Rio e Janeiro, 2002. p. 172.

GOZZO, Débora. Pacto Antenupcial. São Paulo. Saraiva, 1992.

HIRONAKA, Giselda Maria Fernandes Novaes. Concorrência do companheiro e do cônjuge na sucessão dos descendentes. In: FARIAS, Cristiano Chaves de (Org.). Temas atuais de direito e processo de família. 1 . ed. Rio de Janeiro: Lúmen Juris, 2004. p. 496- 525.

LEITE, Eduardo de Oliveira. Direito Civil Aplicado: Direito de Família. v. 5. São Paulo: RT, 2005.

LÔBO, Luiz Paulo Netto. Constitucionalização do Direito Civil. Jus Navegandi, Teresina, ano 3, n. 33, jul. 1999. Disponível em: <http:// www1.jus.com.br/doutrina/texto.asp?id=507 $>$. Acesso em: 30 maio 2004.

LORENZETTI, Ricardo. Fundamentos do direito privado. São Paulo: Revista dos Tribunais, 1998.

MADALENO, Rolf. Do regime de bens entre os cônjuges. In: DIAS, Maria Berenice; PEREIRA. Rodrigo da Cunha. (Coords.) Direito de Família e o Novo Código Civil. 2. ed. Belo Horizonte: Del Rey, 2002.

OLIVEIRA, José Sebastião de. Fundamentos Constitucionais do Direito de Família. São Paulo: Editora Revista dos Tribunais, 2002.

PERLINGIERI, Pietro. Perfis do Direito Civil: Introdução ao Direito Civil Constitucional. Trad. Maria Cristina De Cicco. 3. ed. rev. e ampl. Rio de Janeiro: Renovar, 1997.

RIZZARDO, Arnaldo. Direito de família: Lein. 10.406, de 10.01.2002. Forense: Rio de Janeiro, 2005.

ROCHA, Sílvio Luiz Ferreira da. Introdução ao Direito de Família. São Paulo: RT, 2004. 
RODRIGUES, Sílvio. Direito civil: Direito de família. 27. ed. Atual. por Francisco José Cahali, com anotação ao novo Código Civil. São Paulo: Saraiva, 2002.

SANTOS, Luiz Felipe Brasil. A mutabilidade do regime de bens. Disponível em: <http://www. migalhas.com.br/mostra_noticia_ articuladas. aspx?cod=2295>. Acesso em: 30 junho 2005.

SARLET, Ingo Wolfgang Sarlet. Dignidade da pessoa humana e direitos fundamentais na Constituição Federal de 1988. Porto Alegre: Livraria do Advogado, 2001.

SEREJO, Lourival. Direito Constitucional da Família. Belo Horizonte: Del Rey, 1999.

VENOSA, Silvio de Salvo. Direito Civil: Direito de Família. 3. ed. São Paulo: Atlas, 2003. v. 6 WALD, Arnoldo. O Novo Direito de Família. 14. ed., ver. e atual. São Paulo: Saraiva, 2002. 